Jyotsna Wig MD, Manohar Sharma MD, Neelu Baichoo MD, Anil Agarwal MD

\title{
Nicardipine and verapamil attenuate the pressor response to laryngoscopy and intubation
}

In a prospective, double-blind study, we compared the efficacy of iv nicardipine hydrochloride and verapamil hydrochloride in attenuating the cardiovascular responses to laryngoscopy and tracheal intubation, in 45 patients undergoing elective surgery with general anaesthesia. Patients were allocated randomly to one of three groups of 15 patients. Patients in Group I received saline while those in Groups II and III received nicardipine hydrochloride, $0.03 \mathrm{mg} \cdot \mathrm{kg}^{-1}$ or verapamil hydrochloride, 0.1 $\mathrm{mg} \cdot \mathrm{kg}^{-1}$ iv three minutes before laryngoscopy and intubation. Patients in Group I showed the greatest increase in SBP 25.4 $\pm 2.2 \mathrm{mmHg}$ and HR $35.7 \pm 3.8$ beats $\cdot \mathrm{min}^{-1}$ at one minute after intubation $(P<0.001)$, and these changes persisted throughout the study period albeit with decreasing magnitude. After drug administration, patients in Groups II and III demonstrated increases in $H R$ of $26 \pm 2.4$ and $15.1 \pm 2.2$ beats min $^{-1}$ and decreases in SBP of $24.8 \pm 2.0$ and 18.8 $\pm 2.4 \mathrm{mmHg}$ respectively $(P<0.001)$. It is concluded that nicardipine and verapamil are effective in attenuating pressor responses to laryngoscopy and intubation but did not control the tachycardia.

Cette étude prospective et à double insu compare l'efficacité de l'hydrochlorure de nicardipine et de l'hydrochlorure de vérapamil utilisés pour atténuer la réponse cardio-vasculaire à la larynogscopie et à lintubation de la trachée chez 45 patients soumis à une chirurgie programmée sous anesthésie générale. Les patients sont répartis au hasard à un de trois groupes de

\section{Key words}

ANAESTHETIC TECHNIQUES: laryngoscopy, tracheal intubation;

PHARMACOLOGY: verapamil, nicardipine.

From the Department of Anesthesiology, PGIMER,

Chandigarh and the Sanjay Gandhi Post Graduate Institute of Medical Sciences, Lucknow.

Address correspondence to: Dr. Jyotsna Wig, 8-H/5 Sector-

12 PGI Campus, Chandigarh 160012 - India.

Accepted for publication 27th July, 1994.
15 patients. Les patients du groupe I reçoivent du soluté physiologique alors que les groupes II et III reçoivent soit de l'hydrochlorure de nicardipine $0,03 \mathrm{mg} \cdot \mathrm{kg}^{-l}$ ou de l'hydrochlorure de vérapamil $0,1 \mathrm{mg} \cdot \mathrm{kg}^{-1}$ trois minutes avant la laryngoscopie et lintubation. Les patients du groupe I manifestent l'augmentation la plus importante de PAS à 25,4 $\pm 2,2 \mathrm{mmHg}$ et de Fc 35,7 $\pm 3,8 \mathrm{~b} \cdot \mathrm{min}^{-1}$ une minute après lintubation $(P<$ $0,001)$ et ces changements persistent pendant la période d'étude mais en diminuant. Après l'administration de la drogue, les patients du groupe II et III manifestent des augmentations de la Fc de $26 \pm 2,4$ et de $2,2 \mathrm{~b} \cdot \mathrm{min}^{-1}$ et des baisses de PAS de 24,8 $\pm 2,0$ et de $18,8 \pm 2,4 \mathrm{mmHg}$ respectivement $(P<$ $0,001)$. En conclusion, la nicardipine et le vérapamil atténuent la réponse vaso-pressive de la laryngoscopie et de lintubation mais ne contrôlent pas la tachycardie qui en résulte.

Laryngoscopy and tracheal intubation are known to result in transient hypertension, tachycardia and arrhythmias which can be deleterious in patients with systemic hypertension, coronary artery disease, aortic aneurysms, intracranial aneurysms and cerebrovascular disease. ${ }^{1-5}$ Various pharmacological attempts have been made to attenuate these responses. These include opioids, ${ }^{6}$ deep anaesthesia, ${ }^{7}$ local anaesthetics, ${ }^{8}$ vasodilators, ${ }^{9}$ alpha and beta sympathetic blocking agents ${ }^{10}$ and calcium channel blocking drugs. "

The calcium channel blocking drugs used for attenuation of these cardiovascular responses include intravenous verapamil, ${ }^{11,12}$ intravenous diltiazem ${ }^{13}$ and intravenous nicardipine hydrochloride. ${ }^{14,15}$ In the present study we compared the efficacy of two calcium channel blocking agents, nicardipine hydrochloride, a dihydropyridine derivative and verapamil hydrochloride, a papaverine derivative, for attenuation of the pressor responses to laryngoscopy and intubation.

\section{Methods}

Forty-five adult patients of ASA grades I-II, undergoing elective surgery, were selected for the present study. Eth- 
ical clearance was obtained from the institute ethics committee and informed consent was obtained from the patients. Those with major systemic illness, pregnant women and lactating mothers, and patients in whom intubation took more than $30 \mathrm{sec}$ were excluded from the study. Premedication was with diazepam $0.15 \mathrm{mg} \cdot \mathrm{kg}^{-1}$ po the night before surgery and repeated $90 \mathrm{~min}$ before surgery. In addition, morphine sulphate $0.15 \mathrm{mg} \cdot \mathrm{kg}^{-1}$, promethazine hydrochloride $0.5 \mathrm{mg} \cdot \mathrm{kg}^{-1}$ were administered im $45 \mathrm{~min}$ before surgery.

In the operating theatre each patient was connected to a multichannel monitor Horizon 1000 for continuous ECG display and non-invasive blood pressure and heart rate measurements. Base line recordings of systolic, diastolic and mean blood pressure and heart rate were made. Blood gas analysis was also done at this time. A separate ECG recorder was connected to patients for recording of any relevant ECG changes.

Patients were randomized to receive either normal saline (Group I), $0.03 \mathrm{mg} \cdot \mathrm{kg}^{-1}$ nicardipine hydrochloride (Group II), or $0.1 \mathrm{mg} \cdot \mathrm{kg}^{-1}$ verapamil hydrochloride (Group III), three minutes before tracheal intubation. Each injection was made up to a volume of $5 \mathrm{ml}$ and its nature was unknown to the observer. The drug/saline injection was followed two minutes later by thiopentone $5 \mathrm{mg} \cdot \mathrm{kg}^{-1}, i v$ over $30 \mathrm{sec}$, followed by succinylcholine, $1.5 \mathrm{mg} \cdot \mathrm{kg}^{-1}$. Artificial ventilation was commenced via a face mask using a Magill circuit. Thirty seconds later, i.e., three minutes after the drug/saline injection, laryngoscopy was performed and the trachea was intubated. Anaesthesia was maintained with $67 \%$ nitrous oxide in $\mathrm{O}_{2}$ and pancuronium was used for muscle relaxation. No other inhalational agent was used.

$A$ second $A B G$ analysis was done after intubation and analysed to ensure normocarbia. Readings of systolic, diastolic and mean blood pressures and heart rate were taken after the injection of the drug/saline at the following times:

- D 60: $60 \mathrm{sec}$ after administration of drug/saline.

- D 120: $120 \mathrm{sec}$ after administration of drug/saline and coinciding with administration of thiopentone.

- D 150: $150 \mathrm{sec}$ after administration of drug/saline and coinciding with administration of suxamethonium.

- L: At laryngoscopy.

$I_{1}, I_{2}, I_{3}, I_{5}$ every minute for five minutes and then $I_{10}$, $I_{15}, I_{20}, I_{25}, I_{30}, I_{35}$ every five minutes thereafter for up to $35 \mathrm{~min}$ after intubation.

The data collected were analysed using paired Student's $t$ test for comparison within the group, repeated measures ANOVA for differences among the three groups and Student's unpaired $t$ test for differences between individual groups. Post Hoc test (Newman Keul's) was also applied for pair wise comparison.

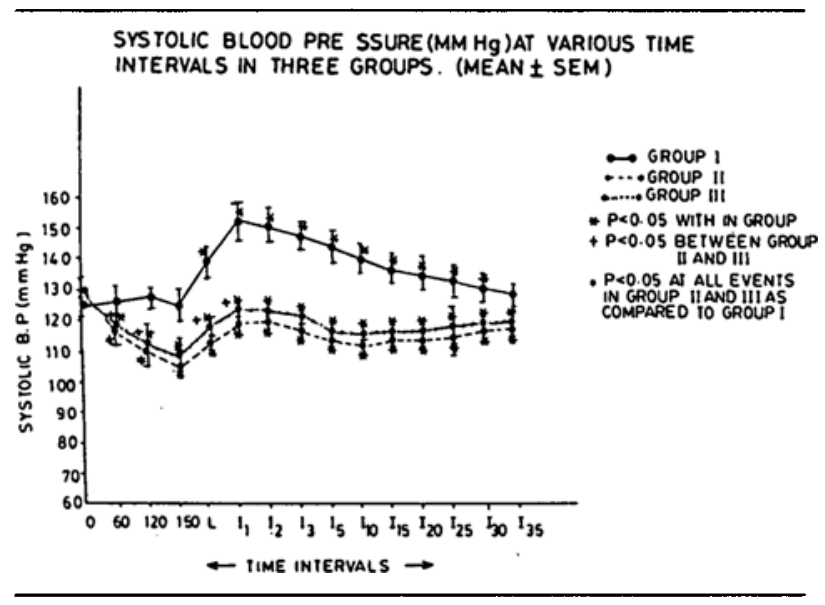

FIGURE I Changes in systolic blood pressure.

\section{Results}

There were no differences between the three groups with respect to mean age and weight $(32.3 \pm 3.4 \mathrm{yr}$ and 52.7 $\pm 3.5 \mathrm{~kg}$ in Group $\mathrm{I}, 30.1 \pm 2.9 \mathrm{yr}$ and $54.7 \pm 3.2$ $\mathrm{kg}$ in Group II and $33.0 \pm 2.9 \mathrm{yr}$ and $53.4 \pm 3.3 \mathrm{~kg}$ in Group III). The baseline cardiovascular variables (SBP, DBP, MBP and HR) were comparable $(P>0.05)$.

\section{Changes in systolic blood pressure (SBP)}

In Group I, a marked increase in SBP occurred during laryngoscopy (L), which reached its peak, $25.4 \pm 2.2$ $\mathrm{mmHg}(P<0.001)$ above basal value, at $\mathrm{I}_{1}$ and the peak was sustained until $I_{2}$. The SBP remained above basal level until $1_{30}(P<0.001)$ (Figure 1). In Groups II and III the mean maximum decrease in SBP was seen at D150, measuring $24.8 \pm 2.08 \mathrm{mmHg}(P<0.001)$ and $18.8 \pm 2.4 \mathrm{mmHg}(P<0.001)$ respectively. In Group II, following laryngoscopy and intubation, SBP always remained below the basal value, until the end of the study period $(P<0.05$, Figure 1). In Group III, SBP was comparable to the basal value at $I_{1}$, after which it decreased and remained so throughout the study (Figure 1).

\section{Changes in diastolic blood pressure (DBP)}

Apart from changes in magnitude and duration, the changes of DBP were similar to those of SBP. The maximum change seen in DBP was $+23 \pm 3.0 \mathrm{mmHg}(P$ $<0.001)$ at $\mathrm{I}_{1}$ in Group $\mathrm{I},-14.5 \pm 1.4 \mathrm{mmHg}(P<$ $0.001)$ at D150 in Group II and $-12.73 \pm 1.1 \mathrm{mmHg}$ $(P<0.001)$ at D150 in Group III. In Groups II and III, DBP was same at all times except for a greater decrease in Group II at D120 (Figure 2).

\section{Changes in mean blood pressure (MBP)}

The pattern of changes in MBP was similar to SBP and DBP (Figure 3). 
DIASIOLIC BLOOD PRESSURE ( $\mathrm{mmHg}$ ) AT VARIOUS TIME NTERVALS IN THE 3 GROUPS (MEAN \pm SEM)

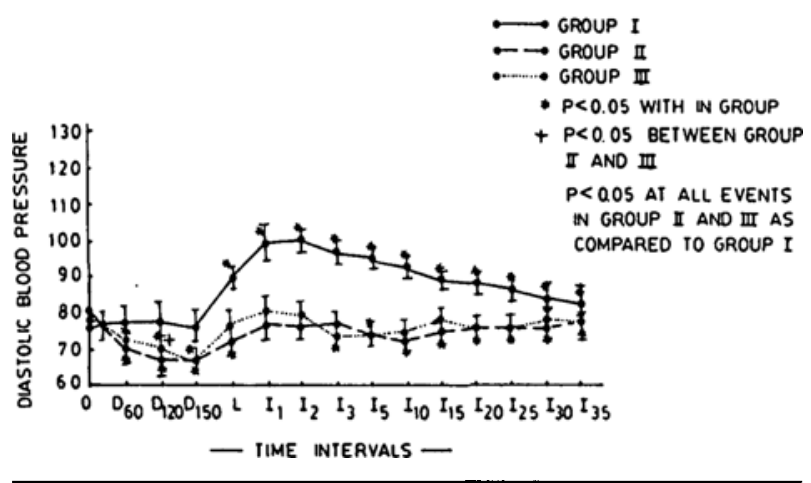

FIGURE 2 Changes in diastolic blood pressure.

\section{Changes in heart rate (HR)}

Group I had the greatest increase in heart rate (HR) after tracheal intubation, compared with Groups II and III (Figure 4). In Group I, HR increased with laryngoscopy and intubation $\left(35.7 \pm 3.8\right.$ beats $\mathrm{min}^{-1}, P<$ 0.001 ) and remained above the basal levels throughout the study. In Groups II and III, HR increased after drug administration, but the peak increase in HR was seen at $\mathrm{I}_{1}$ measuring $26 \pm 2.5$ beats $\cdot \mathrm{min}^{-1}$ in Group II and $15.1 \pm 2.17$ beats $\cdot \min ^{-1}$ in Group III (Figure 4). The HR remained higher in Group II than in Group III ( $P$ $<0.05$ ) except at $I_{1}$ (Figure 1).

\section{Discussion}

Calcium channel blocking agents are widely used for their cardiovascular and cerebrovascular actions. ${ }^{16}$ Verapamil is the treatment of choice in supraventricular tachycardias and a useful antihypertensive and antianginal agent. It has also been used for successful attenuation of the cardiovascular responses to laryngoscopy and intubation. ${ }^{11,12}$ However, it cannot be administered safely with volatile anaesthetic agents, ${ }^{17}$ or beta adrenergic blocking agents, ${ }^{18,19}$ in patients who have poor left ventricular function. It can also potentiate neuromuscular blockade. ${ }^{20}$

In this respect, nicardipine has been combined with digoxin $^{21}$ and beta blocking agents 2,23 and has no neuromuscular blocking effect. However, when used with inhalational agents it may cause excessive hypotension. ${ }^{24}$

Puri et al. (1986), using higher doses of morphine ( 0.2 $\left.\mathrm{mg} \cdot \mathrm{kg}^{-1}\right)$ and thiopentone $\left(5.5 \mathrm{mg} \cdot \mathrm{kg}^{-1}\right)$, achieved better control of heart rate responses using verapamil 0.1 $\mathrm{mg} \cdot \mathrm{kg}^{-1} \dot{\boldsymbol{N}}$ one min before induction. " Nishikawa and Namiki (1989), on the other hand, using the same dose of verapamil after succinylcholine could not control hypertension and tachycardia. ${ }^{12}$ This could have been due

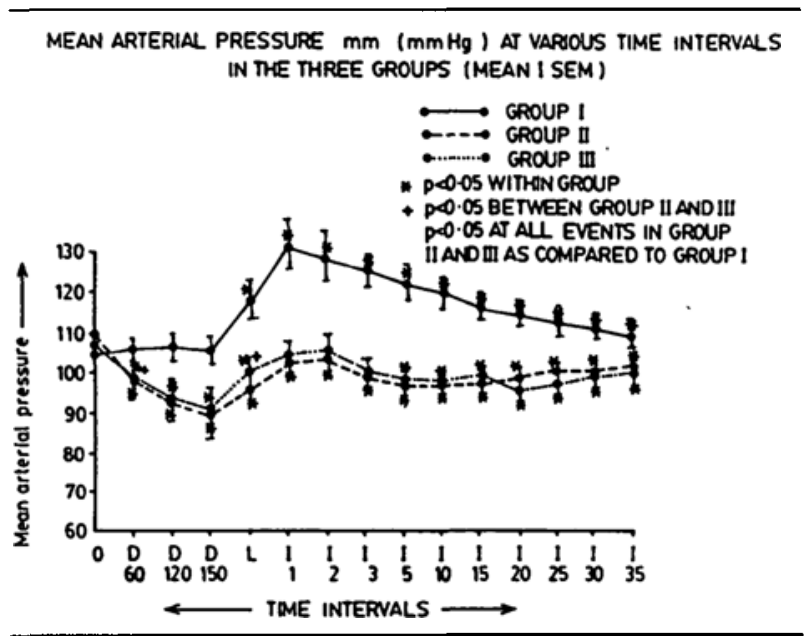

FIGURE 3 Changes in mean blood pressure.

heART RATE ( BEATS MINUTE-1) AT VARIOUS TIME NTERVALS IN THE THREE GROUPS (MEAN $\perp$ SEM)
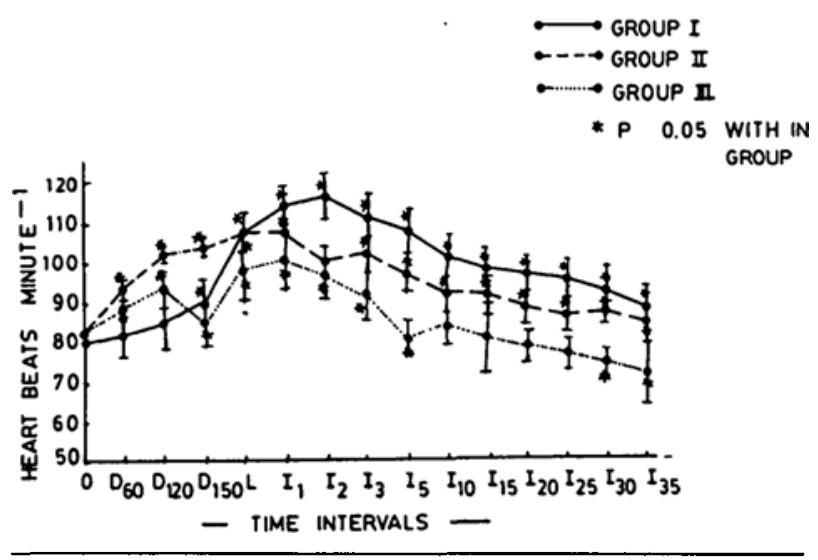

FIGURE 4 Changes in heart rate.

to two factors. First, the time allowed for verapamil to act (one min) was not sufficient for its peak action. Secondly, precurarisation may result in tachycardia and hypertension. ${ }^{25}$ In our study, we achieved control of hypertension with verapamil but the tachycardia could not be controlled.

Our patients showed a greater decrease in systemic blood pressure with nicardipine than described by Mikawa et al. (1990) ${ }^{14}$ and Omote et al. (1992), ${ }^{15}$ perhaps because, in these two studies, opioid premedication was not used.

Our study shows that nicardipine and verapamil are effective in attenuating the hypertensive response to laryngoscopy and tracheal intubation, but neither controlled the resulting tachycardia.

In summary, calcium channel blockers provide satisfactory control of hypertension but some other agents, 
e.g., opioids, may be needed to attenuate the tachycardia resulting from laryngoscopy and intubation.

\section{References}

1 Forbes $A M$, Dally FG. Acute hypertension during induction of anaesthesia and endotracheal intubation in normotensive man. Br J Anaesth 1970; 42: 618-24.

2 Katz RL, Bigger JT Jr. Cardiac arrhythmias during anesthesia and operation. Anesthesiology 1970; 33: 193-213.

3 Prys-Roberis C, Greene LT, Meloche R, Foëx P. Studies of anaesthesia in relation to hypertension. II: Haemodynamic consequences of induction and endotracheal intubation. Br J Anaesth 1971; 43: 531-47.

4 Prys-Robert C, Foëx P, Biro GP, Roberts JG. Studies of anaesthesia in relation to hypertension. V: Adrenergic betareceptor blockade. Br J Anaesth 1973; 45: 671-80.

5 Fox EJ, Sklar GS, Hill CH, Villanueva $R$, King $B D$. Complications related to the pressor response to endotracheal intubation. Anesthesiology 1977; 47: 524-5.

6 Crawford DC, Fell D, Achola KJ, Smith G. Effects of alfentanil on the pressor and catecholamine responses to tracheal intubation. Br J Anaesth 1987; 59: 707-12.

7 King BD, Harris LC Jr, Greifenstein FE, Elder JD Jr, Dripps $R D$. Reflex circulatory responses to direct laryngoscopy and tracheal intubation performed during general anaesthesia. Anesthesiology 1951; 12: 556-66.

8 Stoelting $R K$. Circulatory changes during direct laryngoscopy and tracheal intubation: influence of duration of laryngoscopy with or without prior lidocaine. Anesthesiology 1977; 47: 381-3.

9 Kamra S, Wig J, Sapru RP. Topical nitroglycerine. A safeguard against pressor responses to tracheal intubation. Anaesthesia 1986; 41: 1087-91.

10 Ramakrishna V, Wig J, Singh H, Sapru RD. Can labetalol be used to attenuate the cardiovascular responses to laryngoscopy and endotracheal intubation? Journal of Anaesthesiology and Clinical Pharmacology 1988; 4: 227-32.

11 Puri GD, Singh $H$, Batra $Y K$. Attenuation of pulse rate and blood pressure response to laryngoscopy and intubation with verapamil. Indian J Med Res 1986; 548-51.

12 Nishikawa T, Namiki A. Attenuation of the pressor response to laryngoscopy and tracheal intubation with intravenous verapamil. Acta Anaesthesiol Scand 1989; 33: 232-5.

13 Mikawa K, Ikegaki J, Maekawa N, Goto R, Kaetsu H, Obara $H$. The effect of diltiazem on the cardiovascular response to tracheal intubation. Anaesthesia 1990; 45: 289-93.

14 Mikawa $K$, Obara $H$, Kusunoki M. Effect of nicardipine on the cardiovascular response to tracheal intubation. $\mathrm{Br} \mathrm{J}$ Anaesth 1990; 64: 240-2.

15 Omote $K$, Kirita A, Namiki A, Iwasaki $H$. Effects of ni- cardipine on the circulatory responses to tracheal intubation in normotensive and hypertensive patients. Anaesthesia 1992; 47: 24-7.

16 Fleckenstein $A$. History of calcium antagonists. Circ Res 1983; 52: 113-6.

17 Merin RG. Calcium channel blocking drugs and anesthetics: is the drug interaction beneficial or detrimental? (Editorial). Anesthesiology 1987; 66: 111-3.

18 Opie LH. Drugs and the heart III. Calcium antagonists. Lancet 1980; 1: 806-10.

19 Jones RM. Calcium antagonists: In: Atkinson RS, Adams AP (Eds.). Recent Advances in Anaesthesia and Analgesia, 15th ed. Edinburgh: Churchill-Livingstone 1985; 89-106.

20 Durant NN, Nguyen N, Katz RL. Potentiation of neuromuscular blockade by verapamil. Anesthesiology 1984; 60: 298-303.

21 Lessem J, Bellinetto A. Interaction between digoxin and the calcium antagonists nicardipine and verapamil. Clin Ther 1983; 5: 595-602.

22 Roussean MF, Etienne J, Van Mechelen H, Veriter C, Pouleur $H$. Hemodynamic and cardiac éffects of nicardipine in patients with coronary artery disease. J Cardiovasc Pharmacol 1984; 6: 833-9.

23 Kolloch $R$, Stumpe KO, Overlack A. Blood pressure, heart rate and $\mathrm{A}-\mathrm{V}$ conduction responses to nicardipine in hypertensive patients receiving atenolol. Br J Clin Pharmacol 1985; 20: 130S-4S.

24 Ray DC, Drummond GB. Haemodynamic responses to nicardipine in humans anaesthetised with halothane. Anaesthesia 1989; 44: 382-5.

25 Kautto UM. Effects of precurarization on blood pressure and heart rate changes induced by suxamethonium facilitated laryngoscopy and intubation. Acta Anaesthesiol Scand 1981; 25: 391-6. 